\title{
The Dictate of the Unconscious: The Latent Meaning of a Philosophical Text
}

\section{Hynek Tippelt ${ }^{1}$}

\begin{abstract}
The aim of this study is to outline the psychoanalytic method of interpretation in its application to a philosophical text. The nature of philosophical creativity is illustrated by comparison with the laws of dream activity and the concept of primary process thinking. The concept of a "pride system" (Karen Horney) is used to interpret the specifically philosophical diction. The study shows the possibility of reading a philosophical text as a kind of declaration confirming the importance of its author, fulfilling their unconscious desire to prove the impossibility of "falling out of this world" (Sigmund Freud). The concept of the three archetypal ontological primordial images, inspired by Erikson's reflections and elaborated in other texts of the present author, is reformulated as a distinction of three philosophical styles: disciplined and paternalistic, focused on strict rule and order; sympathetic and maternalistic, focused on acceptance, equality and positive home atmosphere; and "nonsubstantially" (Egon Bondy) open, guided by the image of the "preparental center" (Erik Erikson) and primarily focusing on the value of freedom.
\end{abstract}

Keywords: Philosophical text, psychoanalysis, ontology, projection, magical thinking, New Age, nonsubstantial ontology

\footnotetext{
${ }^{1}$ Filozofická fakulta Univerzity Jana Evangelisty Purkyně v Ústí nad Labem, Pasteurova 3544/1, 40096 Ústí nad Labem, Czech Republic, hynek.tippelt@ujep.cz .
} 


\section{Introduction}

It is a well-known peculiarity of philosophy as a field of knowledge that one of its most important questions is what it is. While the importance of other disciplines is often obvious even to non-experts, or at least is not questioned by them, the meaning of philosophy is rather unclear. The question of what philosophy is may even seem the more difficult the more philosophical texts one has read and the more one knows about philosophers. While in the thought-world of traditional metaphysicians, modern gnoseologists and romantic idealists it occupied the position of the base or culmination of a unified building of all knowledge ${ }^{2}$ the queen of all sciences, today it plays the role of a court jester. At the same time, history suggests that, unlike exact knowledge, philosophical knowledge is not cumulative. Philosophers follow each other in terms of inspiration rather than accepting already proven truths and developing them through their research. A philosopher's closest disciple usually turns out to be their fiercest critic, and so it seems that the meaning of philosophy is something quite different from an unbiased knowledge of reality or the sharing of love for wisdom.

Certainly, philosophy has sometimes been, is, or can be, cognition as well as love. However, if its practice sometimes does not confirm any of the stated intentions (cognition, love), it does not mean that it lacks meaning completely. It can have many different functions and satisfy many different desires. The application of the psychoanalytic concept of the unconscious proved to be schematic, but heuristically beneficial at this point - starting with Sigmund Freud, who devoted a few lines to the unconscious aspects of philosophy. ${ }^{3}$ Lewis Stuart Feuer, ${ }^{4}$ Morris Lazerowitz, ${ }^{5}$ John Oulton Wisdom ${ }^{6}$ and Charles Hanly ${ }^{7}$ followed him more systematically. The most ambitious attempt to interpret the unconscious aspects of philosophical systems and philosophical activities was made by Ben-Ami Scharfstein in The Philosophers: Their Lives and the Nature of their Thought. ${ }^{8}$ Among Czech authors, the inspiring thinker Hugo Siroký considered the unconscious side of philosophizing. ${ }^{9}$ I have tested the psychoanalytic method of interpretation of philosophical thinking in several shorter studies ${ }^{10}$ and evaluated it in a series of monographs. ${ }^{11}$

\footnotetext{
2 Philosophy was placed in close vicinity of the supposed centers of power.

${ }^{3}$ For a systematic overview of Freud's views on philosophy, cf. Tippelt, H., Výklad afektů. K filosofickým otázkám psychologické práce s nevědomím, Ústí nad Labem 2015.
}

${ }^{4} \mathrm{Cf}$. his excellent study on the selected motifs of Kant's Critique of Pure Reason, Feuer, L. S., Lawless Sensation and Categorial Defense: The Uncouscious Sources of Kant's Philosophy, in: C. Hanly and M. Lazerowitz (eds): Psychoanalysis and Philosophy, International University Press, Inc., New York 1970.

${ }^{5}$ Lazerowitz, M., The Language of Philosophy: Freud and Wittgenstein, Boston, Synthese Library, 1977.

${ }^{6}$ Wisdom, J. O., The Metamorphosis of Philosophy, Cairo, Al-Mooref Press, 1947.

7 Hanly, Ch., Metaphysics and Innateness: A Psychoanalytic Perspective, in: Int. J. Psycho-Anal., no. 69, 1988.

${ }^{8}$ Scharfstein, B.-A., The Philosophers: Their Lives and the Nature of their Thought, Basil Blackwell, 1980.

9 Široký, H., Meze a obzory psychoanalýzy, Praha, Triton, 2001 and Prolegomena k psychologii a psychopathotogii osobnosti: Určeno pro posl. filosof. fak., SPN / Učební texty vys. škol, Praha 1966.

${ }^{10}$ Cf. Tippelt, H., Poražený rebel a jeho asketická hvězda, in: Novotný, Jaroslav and Kružík, Josef (eds.) Nietzsche a člověk, Praha, 2005, p. 146-153; Tippelt, H., Post-pop. O taoismu, zrušení filosofie a obětním beránkovi, in: $E$ LOGOS Electronic Journal for Philosophy, 12(1), VŠE Prague, 2005, ISSN 1211-0442, URL: http://elogos.vse.cz/; Prométheus z Trevíru, in: Ergo, ISSN 1212-8317, UJEP Ústí nad Labem, 2006; Tippelt, H., Filosofie, askeze, rezignace, in: E-LOGOS Electronic Journal for Philosophy, 11(1), VŠE Prague, 2004, ISSN 1211-0442, URL: e-logos.vse.cz; Tippelt, H., Psychologické aspekty filosofické problematiky svobody, in: Ergo, ISSN 12128317, UJEP Ústí nad Labem, 2003, no. 2, p. 31-40.

${ }^{11}$ Cf. Tippelt, H., Výklad afektů. K filosofickým otázkám psychologické práce s nevědomím, ISBN 978-80-7414990-0, Ústí nad Labem 2015, Tippelt, H., Jindy, jinde a jinak. Filosofie a změna paradigmatu očima psychoanalýzy, 
The prototype of psychoanalytic material is a dream. We most often encounter displaced psychic contents in dreams. During dream activities, the limitations of material reality fall and conscious control burdened by moral requirements is eliminated. Freud therefore called the interpretation of dreams the royal path to unconsciousness. Along the lines of the above authors, I also believe that to a large extent, philosophical texts can be approached in a similar way as dreams. I will try to clarify what the similarities between dreaming and philosophizing are, and to outline to what insights such parallels can lead. However, experience convinces me that philosophers are reluctant to hear similar considerations concerning their inner motivation. Perhaps they will find this perspective more palatable if they conceive of the analysis of the latent meaning of the philosophical text as the royal path to the superconscious.

\section{Philosophical creativity}

Not unlike dreaming, philosophizing is characterized by considerable freedom. When writing a philosophical text, the author creates, or at least can create, a completely new world, in many respects even the opposite of the intersubjectively experienced. If they focus on social philosophy, they can completely deviate from empirical reality and weave normative visions or write utopian scenarios. As a theorist of knowledge, they may postulate radical skepticism, although at the same time accepting the impossibility of sticking to it in practical life. If they venture into the field of ontology, they become completely free and can create, in the words of Leibniz, any of the possible worlds. They are offered a wide variety of directions to which they can subscribe, and they can still expect to be considered a philosopher, at least by themselves. Like Marx, they can write about the abolition of philosophy or, like Hume, apologize for pretending to be a philosopher; they can wag their finger instead of writing and, like a dreamer, will be protected by a philosophical license guaranteeing them immunity from unwelcome arguments. Anything from a god to a soccer ball can become the subject of philosophical reflection; one can almost say that philosophy, like a dream, is everything and nothing.

Thus, like dreaming, philosophizing takes place in a realm that does not restrict the free production of ideas, does not hinder associative processes, and allows the fulfillment of repressed desires. The canvases of heaven, social order, and cognitive structures on which the philosopher paints become a projection screen depicting the philosopher's unconscious psyche, insofar as they do not allow themselves to be bound by the adopted methodology. Seen from this angle, the methodological limitations that philosophers take on themselves, in our day more than ever before, are a remarkable anomaly. It is comparable to someone using lucid dreaming to correct their dreams in accordance with the principles of objective reality. It gives the impression of reacting to something traumatic, the presence of which would disrupt the relative freedom of associative production. We may be reminded of Kolakowski's Metaphysical Horror ${ }^{12}$ where he pointed to the frightening dimension of modern philosophical concepts. Perhaps twentieth-century philosophy, with its methodologically "tightened" phenomenological, analytical, and hermeneutic practices leading to postmodern relativism, was a set of attempts to avoid reminiscences of the once glorious visions that had become nightmares for nineteenth-century philosophers.

Prague 2012; Tippelt, H., Narcistická kočka a sadistický pavouk. Mezi spinozismem a psychoanalýzou, Ústí nad Labem 2010.

12 Kolakowski, L., Metaphysical Horror, 1988. Revised edition: University of Chicago Press 2001. 


\section{Primary process thinking}

In the state of being awake, thinking is adapted to contact with external reality; it works with experience and logic, but from a developmental and structural point of view it is only a secondary process. To a large extent, conscious ideas and activities are an expression of unconscious mental processes, following rules related to magical thinking or artistic experience. Psychoanalyst and author of many textbooks Alena Plháková characterizes magical thinking as "syncretism, i.e. a tendency to combine various elements into a global, holistic entity. Syncretic thinking is often distinguished by assuming a causative relationship between things which in fact share only insignificant, superficial similarities. "13 In the unconscious world, creatio ex nihilo is possible and eternity taken for granted, the price of a button can be higher than the price of a coat, and a sprig of parsley can represent the forest in all respects.

Philosophy, like any conscious activity, is largely determined by unconscious motives. At the same time, however, with its specifics that make it parallel to dreaming, it is freed from the ordinary obligations that external reality places on conscious activity. As a proponent of independent knowledge, a philosopher can dictate their version of reality independently of ideology, religion, tradition, common sense, and logic. In essence, they can be limited only by their internal boundaries when postulating, naming, and defining new entities, or when protecting terms from unwelcome use. Philosophy thus proves to be a form of daydreaming, or rather its more active and deliberate alternative, where the subject, completely conscious and protected as by camouflage with philosophical jargon, projects dramas in which they play their unconscious conflicts within a framework whose rules are almost entirely under their control.

\section{The pride system}

In addition to specific semantics, philosophy is characterized by a special urgency related to the degree of general obligation with which philosophical ideas are presented. A remarkable immodesty allows philosophers to believe that, despite all probability, they have discovered the true connections and meanings of things and are able to describe the appearance of the world in terms of eternity (Spinoza) or through the prism of absolute knowledge (Hegel), or the necessary structures of being in the world (Heidegger). An even more resolute variety of pride resounds in the lines of "post-metaphysical" philosophers. Relativists, perspectivists and constructivists - shouldn't they be the first ones to question the meaningfulness of spreading their ideas? If their constructions are only relative and their meaning is clear only from a certain perspective, doesn't this make their clear authorial egocentrism particularly narcissistic? The style of both phenomenologists and analytical philosophers is also particularly uncompromising. The phenomenological method of "bracketing" (Husserl, Ricoeur) may well be used as an alibi that can dispel suspicions of "violence of reason". The analytical linguistic turn (Carnap, Quine), on the other hand, seems to allow identification with normativity, loosening as it were personal responsibility in the bowels of bureaucracy.

Philosophical diction, with a few exceptions (Montaigne, Rorty), is accompanied by an aggressive intention to invalidate competing views, or even by a destructive goal to discontinue the freedom of processes of philosophical creativity. ${ }^{14}$ This approach can be found in a variety of philosophers, from Socrates' disarming irony, through Nietzsche's hammer philosophy, to

\footnotetext{
${ }^{13}$ Plháková, A., Učebnice obecné psychologie, Prague 2003, p. 302.

${ }^{14}$ Cf. Feuer, L. S., The Bearing of Psychoanalysis upon Philosophy, in: Philosophy and Phenomenological Research, vol. 13, no. 3, p. 339.
} 
Wittgenstein's command of silence. The dizzyingly ambitious philosophical self-confidence, which, in agreement with Karen Horney, I see as an expression of the neurotic system of pride, ${ }^{15}$ clearly points to the defensive character of "philosophical violence." The stubbornness of philosophical argumentation, the rigidity typical of philosophers as proponents of a particular direction or method, and intransigence to the approaches of their historical and contemporary colleagues are at least as common as inquisitive listening, flexibility in changing perspectives, or willingness to synthesize partial views. The uninitiated would expect wise and patient discussions where the "dictatorship of the enlightened" often holds the reins.

This typical obsession of philosophers with their own philosophical system, whether original or inherited, the peculiar "fanaticism of the sages" seems to reflect the closeness of philosophers in speeches and texts to the traumatic nuclei of their neurotic complexes. Behind the translucent veil of philosophical discipline, they stage events whose impact has determined their inner life for decades. An ideological adversary, even if they share a philosophical stand akin to their own, must be neutralized, because the situation demands not an unbiased assessment, but supposedly and unconsciously - a struggle for life and death, just as it was at the birth of the trauma (whether real or imagined, caused by an unexpected intense event).

\section{Consolation in the network}

In addition to its already mentioned aggressive and destructive aspect, philosophy undoubtedly has a constructive and conciliatory dimension. While the former is exploited in the presentation and defense of the philosophical system, the latter is realized by its creation. The philosopher, driven by a kind of eternal uprooting that prevents them from feeling at ease in communication, and not infrequently guided by resignation of life since their precocious adulthood, weaves a network of concepts, both traditional and newly introduced, to describe and interpret reality as a single structure, in the most conciliatory manner possible. At the same time, they embroider it with the basic images of their inner life, in the processing of which they try to demonstrate their acceptability and in the context of which they capture their universal meaning.

One of the central philosophical themes is uncertainty, doubt, or in other words the possibility of obtaining certainty and dispelling doubts. While working on the analysis of Martin Luther, E.H. Erikson observed that for a certain type of personality, disrupting the constitution of the so-called sense of basic trust in the earliest childhood leads to hopeless struggles in the search for identity during adolescence, the despair of which opens access to the deepest and most remote planes of existence. ${ }^{16}$ Homo religiosus, as Erikson calls this psychological type, precociously views the seriousness of the philosophical-religious dimension of life and compulsively seeks to answer the questions that belong to the final stage of life, which already guarantees sufficient experience to cope with the authentically philosophical tasks of human existence. Intrusive doubts, exaggerated demands and expectations of truth and certainty, by which they torment others and themselves, can be defeated by the philosopher to the extent that they weave their conceptual network, so to speak, out of themselves, becoming the only ruler of the conceptual universe they operate through their speculative fantasies, i.e. to the extent they work with their own self-invented methods and concepts.

Freud, like many others, observed that one of our fundamental desires was to belong somewhere, to be part of the whole, without having to be afraid of "falling out." When a

\footnotetext{
${ }^{15}$ Cf. Horney, K., Neurosis and Human Growth, New York: Norton 1950.

${ }^{16}$ Erikson, E.H., Young Man Luther: A Study in Psychoanalysis and History, New York: Norton 1958, p. 261.
} 
philosopher weaves their system, they seldom neglect themselves. They usually carefully define the role of philosophy in society or the construction of knowledge. The standard philosophical text, as a universal declaration, confirms the importance of its author, more explicitly, more extensively and with greater precision than is necessary for artistic or technical writing. ${ }^{17}$ While the artist or technician must satisfy predetermined conditions which they do not determine themselves, the philosopher assumes the position of the creator of the world for fear of someone else determining their place - to the extent that they consider the real world to be the one they construct in their conceptual networks. While imagining to be discovering eternal truths, the order of the universe, the laws of social development, or the rhizomatic nature of the "body without organs," 18 they affirm their inseparable position as part of the whole, trying to hold on firmly to fulfill their unconscious desire and prove the impossibility of "falling out of this world." 19

\section{Respect for order}

In my earlier research, I have developed Erikson's idea of fundamental images, which guide the various paths of religious experience, ${ }^{20}$ and formulated a typology of philosophical reasoning based on the symbolic nature of central ontological concepts. ${ }^{21}$ I agree with Erikson in assuming that every spiritual activity involves an idea of the world that is so differentiated that the central image by which it is governed can be identified in the creations of that activity. Our thinking is shaped by the experience of early childhood, and our adult creations naturally reflect primarily the characteristics of those who shaped us, being at the center of our early world. It can be expected that the power of these images should also be manifested stylistically in the textual form of their processing.

Paternalistic thinking, characterized by the qualities typical of paternal education and the masculine approach to the world, is determined in this conception by the ontology of order. To some extent, all philosophical texts strive for order; and yet, as outlined above from several angles, unlike those who aspire to writing scientific articles confined by highly formalized style requirements, the philosopher adopts formal restrictions more-or-less voluntarily. Their compulsive doubt leads them to precision, while their intolerance of restrictions encourages them to be disruptive, condensed, and omissive, to write "poetry," to the extent it is philosophically justifiable to take such license. In many important figures in European philosophy, we can see a clear struggle between these tendencies. The prototypical representative of the paternalistic ontology of order, Immanuel Kant - whose categorical imperative, as the strictest paternal supervision, prevented any deviation from intellectually perceived duty - can be a good example. In his early days, he wrote with a light pen, not far removed from the irony of Voltaire's Candide. In his "critical period", he adopted a particularly cumbersome form, based on rich original terminology, the use of which is sometimes inconsistent. He digressed from the constraints of the "critical" style twice: in the Prolegomena,

\footnotetext{
17 With the possible exception of poets writing about what it is like to be a poet.

18 Cf. Gilles Deleuze and Félix Guattari: A Thousand Plateaus: Capitalism and Schizophrenia, University of Minnesota Press 1987.

${ }^{19}$ Freud, Sigmund, Civilization and its Discontents, New York: Norton 1962. This is a quote from C.D. Grabbe's Hannibal.

20 Erikson, E. H., Young Man Luther: A Study in Psychoanalysis and History, New York: Norton 1958, p. 263-266.

${ }^{21}$ Cf. Tippelt, H., Jindy, jinde a jinak. Filosofie a změna paradigmatu očima psychoanalýzy, Prague 2012; and Tippelt, H., Narcistická kočka a sadistický pavouk. Mezi spinozismem a psychoanalýzou, Ústí nad Labem 2010.
} 
the result is a peculiar mixture, teeming with engaging metaphors among the numbered paragraphs, while in the Basics of the metaphysics of morals we even find a certain confusion.

One of the peak expressions of the paternalistic respect for order is undoubtedly Spinoza's Ethics. For centuries, it has attracted philosophers of various faiths - ranging from Hegel through Nietzsche to contemporary ecological thinkers - with its geometric style striving for unambiguity and evidence, a thematic scope uniting all beings into one network of causes and effects, and the ambition to tell eternal truths about the highest being and to formulate them in a single book. One may ask whether the development of twentieth-century philosophy has weakened the paternalistic demands for discipline to such an extent that philosophy is losing its fertility, the resources of which are in responsible authority rather than subordination to commitments.

\section{Finding a home}

While the image of the father takes on the meaning of order in philosophical thought - Erikson speaks of "the paternal voice of guiding conscience, which puts an end to the simple paradise of childhood and provides a sanction for energetic action" - the image of the mother expresses the motives of love, forgiveness, and acceptance. If the first image brought relief to feelings of guilt and provided an axiological grounding in being oriented towards duty and law, the second image soothes the anxiety of the immensity and uncontrollability of the outside world, offers refuge and a sense of protection. While in the former case, the conceptual network captured the intellectual insight of the world order and involvement in it, the latter uses conceptual threads to weave the maternal arms, intended for carefree rest. The current spiritual atmosphere, marked by confusion and frustration by the disturbed traditions of social ties and tragic nostalgia for broken ecosystems, supports the proliferation of programmatic eclectic movements, often collectively referred to as the New Age. Their common key assumption is the groundbreaking nature of our time. Astrologically it is interpreted as the beginning of the Age of Aquarius; transhumanists see it as a transition to the non-biological substrate of intelligence and consciousness; politically and philosophically it is explained by the revolutionary consequences of unstoppable globalization processes; historians of philosophy speak of a paradigm shift. All these conceptions resound with determinism or historicism, typical of the materialist worldview. They are also united by some form of orientation towards femininity. Thus, many supporters of the coming of the "New Age" look up to James Lovelock with his Gaia hypothesis, all of them sharing hopes for the advent of a gentle and cooperative women's policy.

A specific technique used in the New Age movement is the recording of the so-called channelings, i.e. psychological connections to information sources that deviate from everyday standards - the Akashic field, extraterrestrial civilization, astral beings, etc. Their content may range from more-or-less poetic cosmic visions, through "exo-political statements" of the representatives of galactic hierarchies, to introspective observations based on the interpretation of the most diverse symbols, etc. Verification is left entirely to the intuition of the "channeler"; doubts are overcome by a suggestive feeling of contact with a higher reality/dimension. The blithe disregard for the methodological and gnoseological problems entailed by this technique reflects as it were a sense of closeness and inseparability from the source of truth, the unconscious notion of a kind of umbilical cord that ensures that the information connection is not subject to distortion. The conflict-free acceptance of these channeling revelations is further supported by their kind and soothing tone. Different visions and concepts do not compete because they are tolerated as distinctive approaches equally contributing to the perfection of the universe. The uncompromising coldness of the paternalistic spirit of duty is replaced here by a kind of fatalistic unconditional acceptance and warm harmony. We find a similarly friendly 
face of reality and a close connection to it in Bruno, Goethe, Schelling, and many others. This type of thinking is certainly the more perspectivist, the more alienated we feel from our nature and the more helpless we are in our confusions and fears.

\section{Being oneself}

In addition to the two images that we mentioned as constitutive of our spiritual activity, Erikson introduces a third image, which precedes them in terms of succession in individual psychological development. Erikson characterizes it as "the pure self itself, the unborn core of creation, the - as it were, preparental - center where God is pure nothing... This pure self is the self no longer sick with a conflict between right and wrong, not dependent on providers, and not dependent on guides to reason and reality." 22 The motifs of overcoming contradictions and achieving independence are reminiscent of thinkers such as Eckhart, Böhme and Nietzsche. The absence of "guides to reason and reality" could relate this thinking to maternalistic irrationality. But there is "no donor" - ontological certainties, truth criteria, etc. The benefits of external authorities and guarantors, so highly valued by both parental images, are surpassed by the value of freedom, the tool of which often turns out to be common sense. While parental images include distinct dualistic aspects, a concept of a more-or-less divided reality, this ontology of freedom emphasizes the holistic nature of reality and its internal interconnectedness.

Egon Bondy described this as nonsubstantial ontology, a concept not actually distinguishing its substance and its derived, accidental remnant. If we tried to capture his philosophical style of writing, we would find features of decentralization and equal rights analogous to the nature of his ontological system. In trying to summarize or explain, one comes across too many motifs, their multifaceted connections and, in general, too many original perspectives and arguments, usually not allowing for more than a word for word restatement. I think something similar can be said about the above-mentioned "independent thinkers", Eckhart, Böhme and Nietzsche, and especially the philosophical autobiographies of Augustine and Rousseau, where the independence of this style of thinking probably reaches one of its peaks. All these authors strive to speak for themselves, and therefore leave the comfort zone which protects those devoted to various methods. They do not sacrifice their unquestioned uniqueness to controversy or hiding behind authorities. As if out of excess energy, without any obvious effort to "spread the word", they project a world that corresponds to their experiences of freedom, responsibility, and risk. ${ }^{23}$

\section{Conclusion}

In this study, I have tried to outline the approach to a philosophical text as a production that has a largely unconscious origin. For all activities and products, a distinction can be made between their manifest meaning, which is declared, and their concealed latent sense, which relates to their true motivations. In philosophy, however, unconscious motivations are more pronounced than in special sciences or other fields of knowledge. The degree of freedom that characterizes philosophical creativity brings it closer to projective techniques based on free associations and magical thinking. Not unlike daydreaming, philosophy is guided by the principle of pleasure,

\footnotetext{
22 Erikson, E H., Young Man Luther: A Study in Psychoanalysis and History, New York: Norton 1958, p. 264.

${ }^{23} \mathrm{Cf}$. a discussion of the mutual relations among these three moral qualities in: Fišer, Zb., Útěcha $z$ ontologie: substanční a nesubstanční model v ontologii, Prague: Academia 1967.
} 
providing space for omnipotent and omniscient fantasies and soothing nostalgia for the earliest experiences deprived of a sense of separation and exclusion.

In this perspective, philosophy is a kind of soliloquy, the meaning of which lies in the compensation of narcissistic wounds, Oedipus-like guilt, and other traumatic experiences, thus providing important psychological and introspective material. It has proved fruitful to apply the concept of three archetypal ontological primordial images in textual analysis. A distinction has been made between a disciplined paternalistic style; the motherly diction of close listening, where there is no fear of inaccurate translation; and the "nonsubstantial" openness of essays and aphorisms of autonomous thinkers oriented by the image of the "pre-parental center." Philosophy is too old for us to predict its demise. Paternalistic desires for order, law, and rules can be satisfied by science, technology, and bureaucracy. The need for a mother can be met by religious associations, "social networks" and political institutions. However, the processing of the mystical image of "pure self-existence" is an authentic field of philosophizing, and at least the type of philosophical texts oriented towards this image will undoubtedly survive.

\section{References}

Erikson, E. H., Young Man Luther: A Study in Psychoanalysis and History, New York: Norton 1958

Feuer, L. S., Lawless Sensation and Categorial Defense: The Uncouscious Sources of Kant's Philosophy, in: C. Hanly and M. Lazerowitz (eds): Psychoanalysis and Philosophy, International University Press, Inc., New York 1970.

Feuer, L. S., The Bearing of Psychoanalysis upon Philosophy, in: Philosophy and Phenomenological Research, roč. 13 , č. 3, s. 323-340.

Fišer, Zb., Útěcha z ontologie: substanční a nesubstanční model v ontologii, Praha: Academia 1967.

Hanly, Ch., Metaphysics and Innateness: A Psychoanalytic Perspective, in: Int. J. Psycho-Anal., č. 69, 1988.

Horney, K., Neurosis and Human Growth, New York: Norton 1950.

Kolakowski, L., Metaphysical Horror, 1988. Revised edition: University of Chicago Press 2001.

Lazerowitz, M., The Language of Philosophy: Freud and Wittgenstein, Boston, Synthese Library, 1977.

Plháková, A., Učebnice obecné psychologie, Praha: Academia 2003, s. 302.

Scharfstein, B.-A., The Philosophers: Their Lives and the Nature of their Thought, New York: Basil Blackwell, 1980.

Široký, H., Meze a obzory psychoanalýzy, Praha: Triton, 2001.

Široký, H., Prolegomena k psychologii a psychopathotogii osobnosti : Určeno pro posl. filosof. fak., SPN / Učební texty vys. škol, Praha 1966.

Tippelt, H., Filosofie, askeze, rezignace, in: E-LOGOS Electronic Journal for Philosophy, 11(1), VŠE Prague, 2004, ISSN 1211-0442, URL: e-logos.vse.cz.

Tippelt, H., Jindy, jinde a jinak. Filosofie a změna paradigmatu očima psychoanalýzy, Praha: Togga 2012.

Tippelt, H., Narcistická kočka a sadistický pavouk. Mezi spinozismem a psychoanalýzou, Ústí nad Labem: MINO 2010.

Tippelt, H., Poražený rebel a jeho asketická hvězda, in: Novotný, Jaroslav a Kružík, Josef (ed.) Nietzsche a člověk, Praha, 2005, str. 146-153.

Tippelt, H., Post-pop. O taoismu, zrušení filosofie a obětním beránkovi, in: E-LOGOS Electronic Journal for Philosophy, 12(1), VŠE Prague, 2005, ISSN 1211-0442, URL: http://e-logos.vse.cz/.

Tippelt, H., Prométheus z Trevíru, in: Ergo, ISSN 1212-8317, UJEP Ústí nad Labem, 2006.

Tippelt, H., Psychologické aspekty filosofické problematiky svobody, in: Ergo, ISSN 1212-8317, UJEP Ústí nad Labem, 2003, č. 2, s. 31-40. 
Tippelt, H., Výklad afektů. K filosofickým otázkám psychologické práce s nevědomím, ISBN 978-80-7414-9900, Ústí nad Labem 2015.

Wisdom, J. O., The Metamorphosis of Philosophy, Cairo, Al-Mooref Press, 1947. 